'School of Medicine, Buenos Aires University. Buenos Aires, Argentina.

${ }^{2}$ Medical Education Research Laboratory, Hospital Alemán. Buenos Aires, Argentina. ${ }^{3}$ Department of Mental Health, Hospital Alemán. Buenos Aires, Argentina.

${ }^{4}$ Department of Nursing, Hospital Alemán. Buenos Aires, Argentina.

aLicenciado/a en Enfermería.

Funding: This research received no specific grant from any funding agency in the public, commercial, or not-for-profit sectors.

Recibido el 13 de abril de 2020, aceptado el 15 de julio de 2020 .

Correspondencia a:

Dr. Raúl A. Borracci

Av. Pueyrredón 1640,

(C1118AAT). Buenos Aires, Argentina.

raborracci@gmail.com

Material suplementario en versión digital de la Revista Médica de Chile en: Http://revmedchile.org/ material-suplementario

\section{What patients consider to be a 'good' doctor, and what doctors consider to be a 'good' patient}

\author{
RAÚL A. BORRACCI I,2, JOSÉ M. ÁLVAREZ GALLESIO², \\ GRACIANA CIAMBRONE², CECILIA MATAYOSHI ${ }^{3}$, \\ FERNANDO ROSSI ${ }^{4, a}$, SOLEDAD CABRERA ${ }^{4, a}$
}

\section{ABSTRACT}

Background: From a patient's point of view, an 'ideal' doctor could be defined as one having personal qualities for interpersonal relationships, technical skills and good intentions. However, doctors' opinions about what it means to be a 'good' patient have not been systematically investigated. Aim: To explore how patients define the characteristics of a 'good' and a 'bad' doctor, and how doctors define a 'good' and a 'bad' patient. Material and Methods: We surveyed a cohort of 107 consecutive patients attending a community teaching hospital in February 2019, who were asked to define the desirable characteristics of a good/ bad doctor. Additionally, a cohort of 115 physicians working at the same hospital was asked to define the desirable characteristics of a good/bad patient. Responses were subjected to content analysis. Simultaneously, an algorithm in Python was used to automatically categorize responses throughout text-mining. Results: The predominant patients' perspective alluded to desirable personal qualities more importantly than proficiency in knowledge and technical skills. Doctors would be satisfied if patients manifested positive personality characteristics, were prone to avoid decisional and personal conflicts, had a high adherence to treatment, and trusted the doctor. The text-mining algorithm was accurate to classify individuals' opinions. Conclusions: Ideally, fusing the skills of the scientist to the reflective capabilities of the medical humanist will fulfill the archetype of what patients consider to be a 'good' doctor. Doctors' preferences reveal a "paternalistic" style, and his/her opinions should be managed carefully to avoid stigmatizing certain patients' behaviors.

(Rev Med Chile 2020; 148: 930-938)

Key words: Patients; Patient Preference; Physicians; Physician-Patient Relations; Data Mining.

\section{Cómo definen los pacientes a un buen médico, y cómo definen los médicos a un buen paciente}

Antecedentes: Desde la perspectiva del paciente, un médico "ideal" podría definirse como aquel que tiene cualidades para las relaciones interpersonales, habilidades técnicas y buenas intenciones. Sin embargo, las opiniones de los médicos sobre lo que significa ser un "buen" paciente no se han investigado sistemáticamente. Objetivo: Explorar cómo los pacientes definen las características de un "buen" y "mal" médico, y cómo los médicos definen un "buen" y "mal" 
paciente. Material y Métodos: Encuestamos a una cohorte de 107 pacientes consecutivos que asistieron a un hospital comunitario en febrero de 2019, a quienes se les pidió que definieran las características deseables de un médico bueno/malo. Además, se pidió a una cohorte de 115 médicos que trabajaban en el mismo hospital que definieran las características deseables de un paciente bueno/malo. Las respuestas se sometieron a un análisis de contenido. Simultáneamente, se utilizó un algoritmo en Python para clasificar automáticamente las respuestas mediante minería de texto. Resultados: Los pacientes aludieron que las cualidades personales del médico eran más importantes que la competencia en conocimiento y las habilidades técnicas. Los médicos estarían satisfechos si los pacientes mostraran características positivas de personalidad, fueran propensos a evitar conflictos, tuvieran una alta adherencia al tratamiento y confiaran en el médico. El algoritmo de minería de texto clasificó las opiniones de los encuestados en forma precisa. Conclusiones: Idealmente, fusionar las habilidades del científico con las capacidades reflexivas del médico humanista cumplirá con el arquetipo de lo que los pacientes consideran un "buen" médico. Las preferencias de los médicos revelan un estilo "paternalista", y sus opiniones deben manejarse con cuidado para evitar estigmatizar los comportamientos de ciertos pacientes.

Palabras clave: Pacientes; Preferencia; Médicos; Comunicación; Relación médico-paciente; Minería de datos.

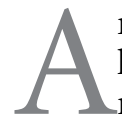
n 'ideal' doctor could be defined as one having personal qualities for interpersonal relationships, proficiency in knowledge, technical skills and good intentions ${ }^{1}$. But beyond these considerations, most doctors are good doctors in the eyes of most patients, and complaints are usually related only to the fact that doctors and patients do not always agree on priorities ${ }^{2}$. Persons who have recently experienced medical care generally give less critical ratings to doctors ${ }^{3}$, and while older patients are tolerant with medical 'paternalism', younger patients tend to highlight doctors' skills in communication and in sharing decision-making ${ }^{4}$. Patients' perceptions regarding doctors' qualities have been explored with various structured questionnaires ${ }^{5-6}$ and occasionally through a qualitative approach with open-ended questions ${ }^{7}$. Though the results of structured questionnaires are easier to analyze, the open enquiry format allows to gather information on patients' beliefs and expectations, not ruled by pre-established categories.

In contrast, doctors' opinions about what it means to be a 'good' patient have not been systematically explored. From the physician's point of view, the implicit characteristics of a 'good' patient would include: doctor-trusting, docility to avoid decisional conflicts, obedience to doctor's commands, high adherence to treatment and continuity of care ${ }^{8}$. Since patients and doctors may have different views or priorities to characterize desirable individual's features, we designed this study with the aim of exploring how hospitalized patients define the characteristics of a 'good' and a 'bad' doctor, and how doctors define a 'good' and a 'bad' patient.

\section{Materials and Methods}

We surveyed a cohort of consecutive patients attending a community teaching hospital in $\mathrm{Fe}$ bruary 2019. The group corresponded to patients hospitalized in a general internal medicine or surgical ward, or in a day-care hospital unit. All patients hospitalized during the study period were considered. Exclusion criteria were dementia, aphasia, no consent or unwillingness to participate, or any difficulty with the Spanish language that prevented them from understanding or answering a questionnaire. Patients were also stratified to evaluate the effect of age, gender, level of education, and perceived health status on responses. Patients invited to participate were interviewed by a researcher in order to inform them that this study would explore their definitions of what 
made a good/bad doctor, that they were not asked to evaluate the care they were receiving during their present hospital stay, and that their responses would not impact on their care. The protocol was evaluated and approved by the Institutional Review Board.

A qualitative approach with an open-ended questionnaire was used to allow the interviewee to give his/her own free hardly influenced answers. Questions were formulated as follows: "According to you, what is an ideal doctor, a doctor you would like to be treated by? How would describe him/ her?", and otherwise "According to you, what is a bad doctor, a physician you would not like to be treated by? How would you describe him/her?" Complete confidentiality was guaranteed and responses were rendered anonymous. Patients' responses were subjected to content analysis performed by a psychologist and a physician (CM and
RAB). Relevant topics extracted from responses were grouped into thematic categories encompassing the characteristics of good/bad doctors as expressed by the patients. A list of key categories previously communicated by Luthy $\mathrm{C}$ et al. ${ }^{7}$ was used to identify and classify patients' responses (Table 1). This list was subsequently refined and enlarged to include unforeseen answers. Categorization of ambiguous responses was discussed and disagreements were solved by consensus.

Additionally, a cohort of physicians working at the same hospital was asked to anonymously respond a similar open-ended questionnaire in order to define the desirable characteristics of a good/bad patient. The questions' structure was: "According to you, what is an ideal patient, a patient you would like to treat? How would describe him/her?", and otherwise "According to you, what is a bad patient, an individual you would not like

\section{Table 1. Categories for 'good' and 'bad' doctor used to classify patients' responses (modified from Luthy C et al. ${ }^{7}$ )}

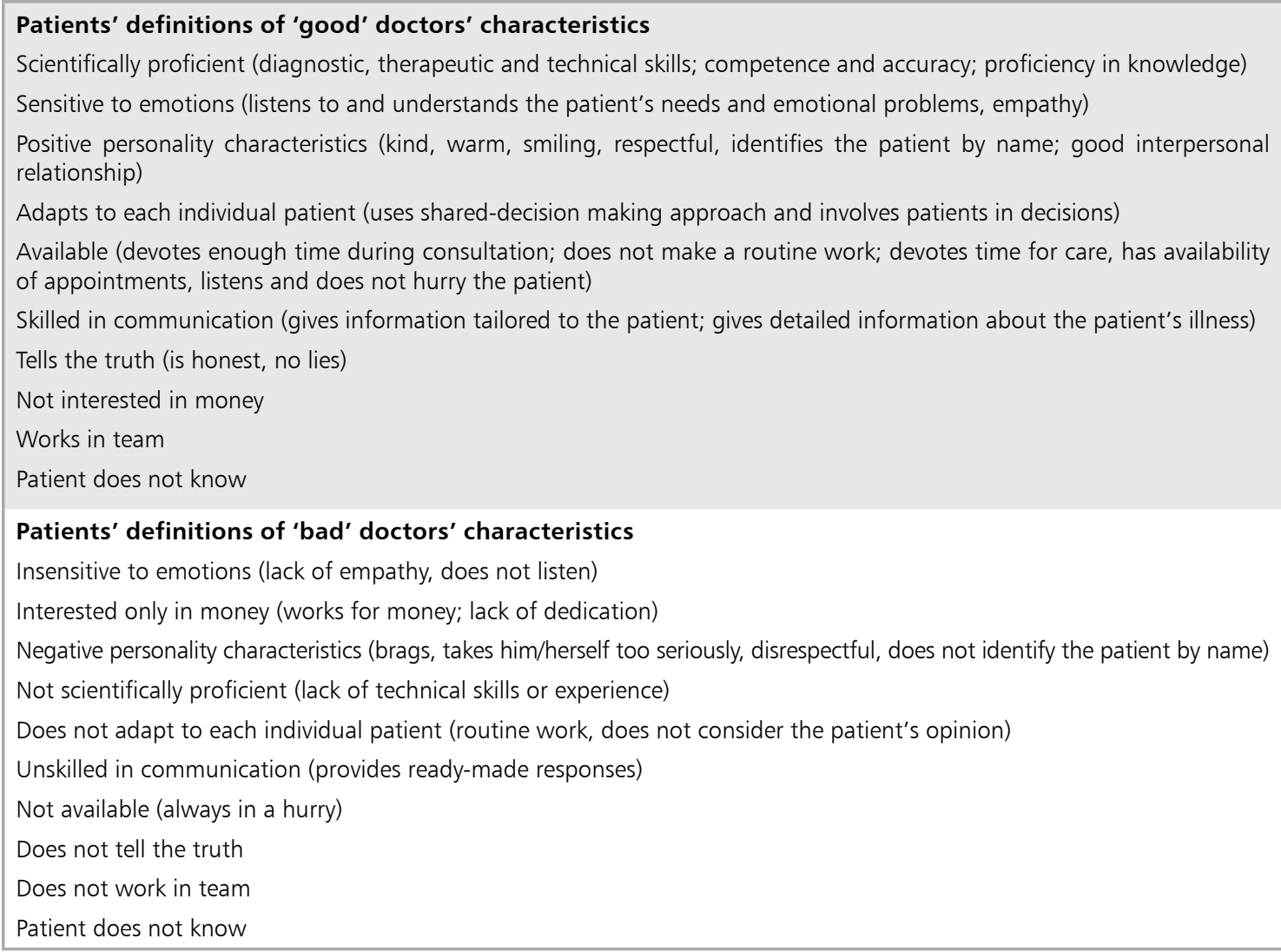


to treat? How would you describe him/her?" Due to lack of previously described categories to classify doctors' responses, we defined by consensus the list of possible characteristics that a 'good' patient would present (Table 2). In this case, the categories of a 'bad' patient were initially defined as the reverse image of the good one. Similarly to the patients' survey analysis, relevant topics obtained from responses were grouped into categories encompassing the characteristics of good/bad patients as communicated by doctors. Physicians' demographic characteristics such as age, gender, medical specialty, and years from graduation were also recorded.

Simultaneously, an algorithm written in Python 3.7.0 (Python Software Foundation. 2001-2018) was used to automatically categorize patients' and physicians' responses by searching selected keywords throughout the free texts (text-mining) (Appendix). Finally, human (psychologist/physician) versus algorithm-based analysis was compared.

Qualitative variables were expressed as absolute values and percentages, and continuous variables as mean, range and standard deviation (SD). Comparison between categories was made with $\chi^{2}$, using the 2-tailed Fisher's exact test when cell expected values were $\leq 5$. IBM SPSS 23.0 Statistics (IBM Corporation, Armonk, NY) was used for statistical analysis.

\section{Table 2. Categories for 'good' patient used to classify doctors' responses (categories for 'bad' patient were initially defined as the reverse image of the 'good' one)}

Doctors' definitions of 'good' patients' characteristics

Doctor-trusting relationship (patient must trust the doctor) No conflicting attitude (patient and family)

Obedience to doctor's commands or suggestions (docility to avoid decisional conflicts)

High adherence to treatment (importance of continuity of care)

Shared decision-making (commitment with self-care)

Skilled in communication

Positive personality characteristics

Doctor does not know

\section{Results}

\section{Patients' responses}

One hundred and seven patients completed the survey. Mean age was 47.1 years (SD 16.2, range 18-77) and 57.0\% were women. Regarding patients' educational level, $8.4 \%$ had attained primary school level, $41.1 \%$ secondary level, and $50.5 \%$ tertiary/university level. Considering patients' self-rated health status, $45.8 \%$ of respondents declared a very good or excellent health status, $45.8 \%$ referred to it as good, and $8.4 \%$ as fair. Table 3 summarizes the patients' responses for what they considered was a 'good' doctor, according to the human and algorithm-based analyses. Comparison between the two analytical methods showed no statistical difference in most categories, except for the "communicational skills" dimension that was more frequently identified by the algorithm than by the human analyzer. Literal descriptions of a 'good' doctor are referred in the following responses. Example 1: "... he/she is respectful, attentive and sincere ... he/she explains everything about the procedures I am going to recei$v e$ ”. Example 2: “... he/she has vocation for service... efficient... responsible”. Example 3: “... he/she generates empathy, confidence... he/she is in a good mood, which conveys that you are not another number".

Undesirable physicians' features as denoted by the same patients are included in Table 4. Comparison between the two analytical methods showed no statistical differences in most categories, except for being "unskilled in communication" that was more frequently indentified by the algorithm than by the human analyzer. Literal descriptions of a 'bad' doctor are referred in the following responses. Example 1: “... he/she seems indifferent and treats a patient simply as a thing..." Example 2: "... he/she is always in a hurry...does not understand that his/her patient is a person with a history and emotions, not just a body to treat...does not listen to his/her patient". Example 3: "... he/she has not the capacity to understand the bad moment the patient is experiencing...”. Regarding gender differences, female patients tended to prefer "sensitive to emotions" physicians, when compared with male respondents ( $51 \%$ versus $35 \%, \mathrm{p}=0.098)$. Younger patients below the mean age ( 47.1 years) considered "communication skills" as a desirable doctor's trait when compared with older individuals $(41 \%$ versus $19 \%, p=0.013)$. Regarding 


\section{Table 3. Patients' definitions to characterize a 'good' doctor}

\begin{tabular}{|c|c|c|c|}
\hline Categories for a 'good' doctor & $\begin{array}{l}\text { Responses, } \mathbf{n}(\%) \\
\text { (human-based } \\
\text { analysis) }\end{array}$ & $\begin{array}{l}\text { Responses, } \mathbf{n}(\%) \\
\text { (algorithm-based } \\
\quad \text { analysis) }\end{array}$ & P-Value \\
\hline $\begin{array}{l}\text { Sensitive to emotions (listens to and understands the patient's } \\
\text { needs and emotional problems, empathy) }\end{array}$ & $47(43.9)$ & $52(48.6)$ & 0.493 \\
\hline $\begin{array}{l}\text { Positive personality characteristics (kind, warm, smiling, } \\
\text { respectful, identifies the patient by name; good } \\
\text { interpersonal relationship) }\end{array}$ & $47(43.9)$ & $41(38.3)$ & 0.405 \\
\hline $\begin{array}{l}\text { Scientifically proficient (diagnostic, therapeutic and technical } \\
\text { skills; competence and accuracy; proficiency in knowledge) }\end{array}$ & $37(34.6)$ & $49(45.8)$ & 0.094 \\
\hline $\begin{array}{l}\text { Skilled in communication (gives information tailored to the } \\
\text { patient; gives detailed information about the patient's illness) }\end{array}$ & $32(29.9)$ & $50(46.7)$ & 0.011 \\
\hline $\begin{array}{l}\text { Available (devotes enough time during consultation; does not } \\
\text { make a routine work; devotes time for care, has availability of } \\
\text { appointments, listens and does not hurry the patient) }\end{array}$ & $20(18.7)$ & $20(18.7)$ & 1.000 \\
\hline Tells the truth (is honest, no lies) & $8(7.5)$ & $8(7.5)$ & 1.000 \\
\hline $\begin{array}{l}\text { Adapts to each individual patient (uses a shared-decision } \\
\text { making approach and involves patients in decisions) }\end{array}$ & $3(2.8)$ & $6(5.6)$ & 0.498 \\
\hline Not interested in money & $0 \quad(0.0)$ & $0 \quad(0.0)$ & 1.000 \\
\hline Works in team & $4(3.7)$ & $4 \quad(3.7)$ & 1.000 \\
\hline Patient does not know & $0 \quad(0.0)$ & $0 \quad(0.0)$ & 1.000 \\
\hline
\end{tabular}

As more than one response was possible, the total is higher than $100 \%$.

Table 4. Patients' definitions to characterize a 'bad' doctor

\begin{tabular}{|c|c|c|c|}
\hline Categories for a 'bad' doctor & $\begin{array}{l}\text { Responses, } \mathbf{n}(\%) \\
\text { (human-based } \\
\text { analysis) }\end{array}$ & $\begin{array}{l}\text { Responses, } \mathbf{n}(\%) \\
\text { (algorithm-based } \\
\text { analysis) }\end{array}$ & P-Value \\
\hline $\begin{array}{l}\text { Negative personality characteristics (brags, takes him/herself } \\
\text { too seriously, disrespectful, does not identify the patient by } \\
\text { name) }\end{array}$ & $64(59.8)$ & $70(65.4)$ & 0.397 \\
\hline Insensitive to emotions (lack of empathy, does not listen) & $30(28.0)$ & $24(22.4)$ & 0.345 \\
\hline Not available (always in a hurry) & $24(22.4)$ & $23(21.5)$ & 0.869 \\
\hline $\begin{array}{l}\text { Unskilled in communication (provides ready-made } \\
\text { responses) }\end{array}$ & $18(16.8)$ & $35(32.7)$ & 0.007 \\
\hline $\begin{array}{l}\text { Not scientifically proficient (lack of technical skills or } \\
\text { experience) }\end{array}$ & $12(11.2)$ & $21(19.6)$ & 0.088 \\
\hline $\begin{array}{l}\text { Does not adapt to each individual patient (routine work, } \\
\text { does not consider the patient's opinion) }\end{array}$ & $5(4.7)$ & $8(7.5)$ & 0.567 \\
\hline Patient does not know & $3(2.8)$ & $3(2.8)$ & 1.000 \\
\hline Does not tell the truth & $3(2.8)$ & $10 \quad(9.3)$ & 0.082 \\
\hline Does not work in team & $2(1.9)$ & $2(1.9)$ & 1.000 \\
\hline $\begin{array}{l}\text { Interested only in money (works for money; lack of } \\
\text { dedication) }\end{array}$ & $0 \quad(0.0)$ & $0 \quad(0.0)$ & 1.000 \\
\hline
\end{tabular}

As more than one response was possible, the total is higher than $100 \%$. 
educational level, patients who attained tertiary or university level preferred "sensitive to emotions" physicians $(56 \%$ versus $32 \%, \mathrm{p}=0.014$ ), whereas those who attained primary or secondary educational level preferentially chose "positive personality traits" $(60 \%$ versus $28 \%, \mathrm{p}<0.001)$. Finally, when patients were divided by self-rated health status, individuals reporting a very good or excellent health status tended to consider the "lack of scientific proficiency" an undesirable characteristic for defining a "bad" doctor ( $18 \%$ versus $5 \%$, $\mathrm{p}=0.061)$. The rest of possible comparisons did not show statistical differences or trends among patients' demographic characteristics (Figure 1) (see also Tables 7 to 11 bis in the supplementary material).
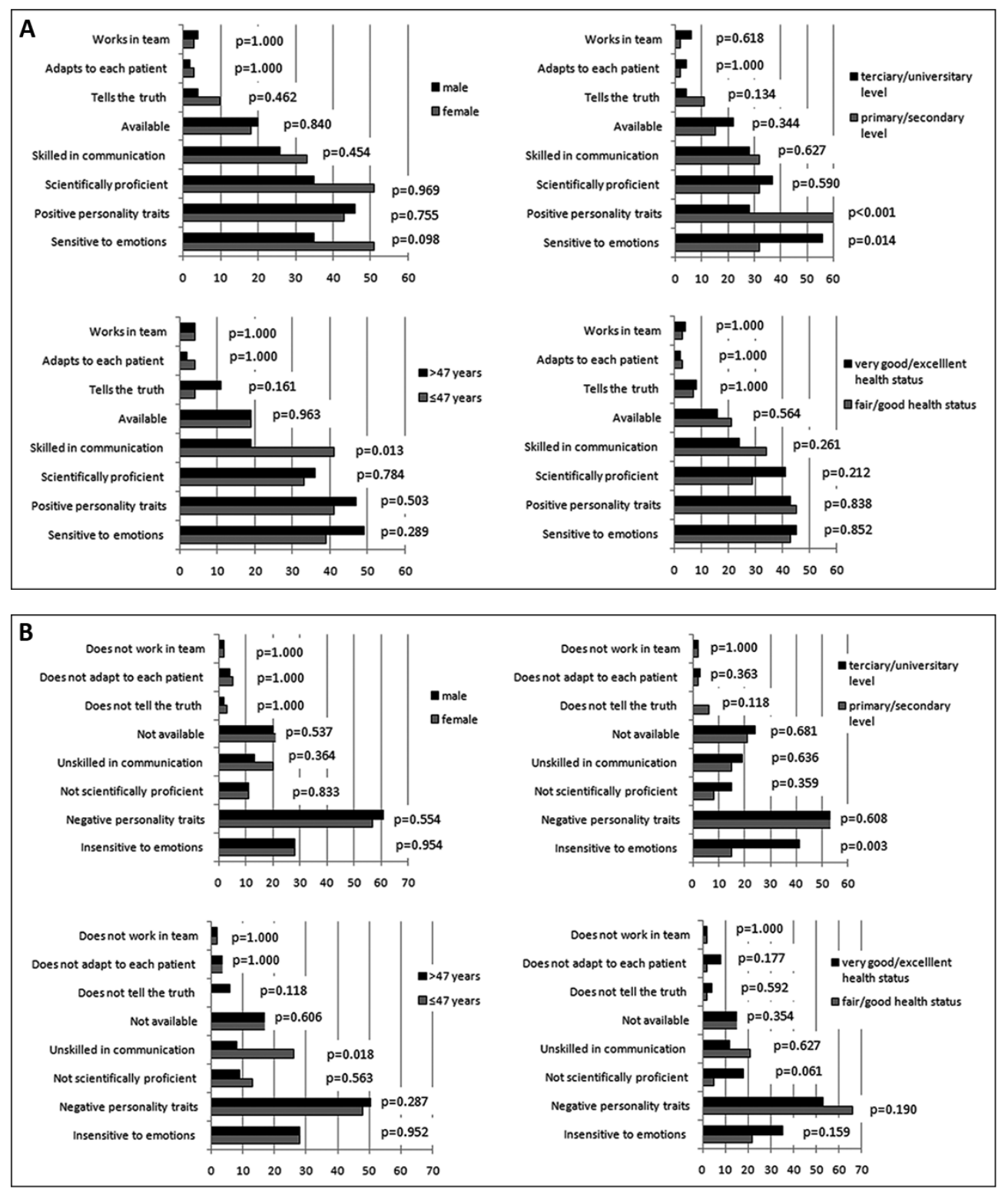

Figure 1. Categories selected by patients for "good" (a) and "bad" (b) doctors according to gender, age, educational level, and self-rated health status (values are expressed as percentages). 


\section{Physicians' responses}

One hundred and fifteen physicians completed the survey. Mean age was 40.4 years (SD 11.5, range 26-65) and 53.0\% were women. Regarding medical specialties, $40.9 \%$ performed a surgical specialty and the rest a clinical one. Mean time from graduation was 14.5 years (SD 9.7). Table 5 summarizes the physicians' responses for what they considered was a 'good' patient, according to the human and algorithm-based analyses. Comparison between the two analytical methods showed no statistical differences in all categories. In order to simplify the analysis, obedience to doctor's commands and adherence to treatment categories were grouped into only one category. A 'good' patient was defined by individual physicians with the following responses. Example 1: “... he/ she pays attention and obeys instructions...he/she is respectful..." Example 2: “... he/she takes care of his/her health... expresses his/her doubts..." Example 3: “... he/she trusts and respects his/her doctor's opinion... does not want to change it or adapt it to his/her preferences... does not constantly question the doctor's opinion...".

Undesirable patients' features as referred by the same physicians are included in Table 6 . Comparison between the two analytical methods showed no statistical differences in most categories, except for the "conflicting attitude" and "sharing decision-making" dimensions that were more frequently indentified by the algorithm than by the human analyzer. Literal descriptions of a

Table 5. Doctors' definitions to characterize a 'good' patient

\begin{tabular}{|lccc|}
\hline Categories for a 'good' patient & $\begin{array}{c}\text { Responses, n (\%) } \\
\text { (human-based } \\
\text { analysis) }\end{array}$ & $\begin{array}{c}\text { Responses, n (\%) } \\
\text { (algorithm-based } \\
\text { analysis) }\end{array}$ & P-Value \\
\hline $\begin{array}{l}\text { Positive personality characteristics (kind, respectful, honest, } \\
\text { educated patient, good interpersonal relationship) }\end{array}$ & $79(68.7)$ & $76(66.1)$ & 0.673 \\
$\begin{array}{l}\text { Obedience to doctor's commands or suggestions (docility } \\
\text { to avoid decisional conflicts, adherence to treatment) }\end{array}$ & $53(46.1)$ & $40(34.8)$ & 0.080 \\
$\begin{array}{l}\text { Skilled in communication (gives detailed information } \\
\text { about the patient's illness) }\end{array}$ & $17(14.8)$ & $14(12.2)$ & 0.562 \\
$\begin{array}{l}\text { Doctor-trusting relationship (patient trusts the doctor) } \\
\text { Shared decision-making (commitment with self-care) }\end{array}$ & $14(12.2)$ & $14(12.2)$ & 1.000 \\
\hline No conflicting attitude (patient and family) & $7(6.1)$ & $11(9.6)$ & 0.326 \\
\hline
\end{tabular}

As more than one response was possible, the total is higher than $100 \%$.

Table 6. Doctors' definitions to characterize a 'bad' patient

\begin{tabular}{|c|c|c|c|}
\hline Categories for a 'bad' patient & $\begin{array}{l}\text { Responses, } \mathbf{n}(\%) \\
\text { (human-based } \\
\text { analysis) }\end{array}$ & $\begin{array}{l}\text { Responses, } \mathbf{n}(\%) \\
\text { (algorithm-based } \\
\text { analysis) }\end{array}$ & P-Value \\
\hline $\begin{array}{l}\text { Negative personality characteristics (unkind, disrespectful, } \\
\text { dishonest, impatient, bad interpersonal relationship) }\end{array}$ & $91(79.1)$ & $97(84.3)$ & 0.306 \\
\hline $\begin{array}{l}\text { No obedience to doctor's commands or suggestions (prone } \\
\text { to generate decisional conflicts, low adherence to treat- } \\
\text { ment) }\end{array}$ & $39(33.9)$ & $42(36.5)$ & 0.679 \\
\hline Conflicting attitude (patient and family) & $20(17.4)$ & $38(33.0)$ & 0.006 \\
\hline $\begin{array}{l}\text { Doctor-trusting relationship (patient does not trust the } \\
\text { doctor) }\end{array}$ & $19(16.5)$ & $25(21.7)$ & 0.314 \\
\hline $\begin{array}{l}\text { Unskilled in communication (unable to give detailed infor- } \\
\text { mation about the patient's illness) }\end{array}$ & $6 \quad(5.2)$ & $13(11.3)$ & 0.149 \\
\hline Sharing decision-making (uncommitted with self-care) & $0 \quad(0.0)$ & $24(20.9)$ & $<0.001$ \\
\hline
\end{tabular}

As more than one response was possible, the total is higher than $100 \%$. 
'bad' patient are stated in the following responses. Example 1: “... he/she is disrespectful, discourteous, intolerant, anxious... does not respect shift schedules...does not comply with medical indications..." Example 2: "... he/she is impatient... distrustful... with a conflicting family...he/she permanently doubts..." Example 3: "... he/she thinks he/she knows more about medicine than the doctor does...".

Physicians' opinions were divided by age below and over the mean value of 40.4 years. Older doctors preferred patients "obedient to doctor's commands and suggestions" ( $63 \%$ versus $35 \%, \mathrm{p}=0.003$ ), whereas younger physicians favored patients with "positive personality traits" (78\% versus $54 \%$, $\mathrm{p}=0.008$ ) when choosing among categories for "good" patients. No age-based differences were observed when selecting categories for "bad" patients.

\section{Discussion}

In this qualitative study, we explored the definitions of what it means to be a 'good' or a 'bad' doctor from a group of hospitalized patients' point of view. Patients' opinions on doctors' positive and negative characteristics were contrasted with the definitions of what it is to be a 'good' or a 'bad' patient from the doctors' perspective.

At a first glance, features selected by patients to define a 'good' or a 'bad' doctor showed that the 'bad' doctor cannot be defined as the reverse image of the 'good' one, since 'bad' doctors were defined more by their negative personality characteristics than by sensitivity to emotions. Although positive/negative personality traits and sensitivity/ insensitivity to emotions were in the foreground in both 'good' and 'bad' doctors, the psychologist and the physician who analyzed the responses recognized that these characteristics were difficult to differentiate from each other.

One approach to defining a 'good' doctor equates the skills of a dedicated scientist and a medical humanist ${ }^{2}$. In the current study, scientific proficiency was ranked in the third place after more humanistic characteristics as sensitivity to emotions and positive personality traits to define a 'good' doctor.

The communication skills in a 'good' doctor were claimed by almost a third of the patients, although the text-mining analysis found them in almost half of respondents. A review of the literature on primary care patients' perspective about how patients want their doctor to communicate revealed specific expectations to be met in medical encounters ${ }^{9}$.

In a recent survey, patients were asked to respond in two words their feelings about the doctor's interview immediately following the clinic visit ${ }^{10}$. Positive words more frequently chosen were: knowledgeable, caring, professional, excellent, and competent. Negative words frequently chosen were: rushed, busy, hurried, uncaring, rude, unconcerned, arrogant, uninterested, and condescending. In this case, positive words predominantly referred to scientific proficiency, whereas negative adjectives suggested poor personality traits. In our study, the positive/negative personality characteristics and the emotional sensitivity/ insensitivity categories ranked both in the first places to define a good/bad doctor.

Regarding what physicians considered to be a good/bad patient, most common categories selected were the positive/negative personality traits and the adherence to doctor's suggestions. At least for the two top categories, 'bad' patients could be defined as the reverse image of a 'good' one. A conflicting attitude of the patient or his/ her family was indicated as an unfavorable characteristic by almost one-fifth of physicians, but this frequency increased to one-third after using the algorithm-based method.

Nearly one-fifth of physicians considered patient trust a desirable characteristic, and less than $10 \%$ cared about the concept of sharing decision-making, although the text-mining analysis duplicated this last proportion, at least for those considered 'bad' patients. Wrede-Sach et al. ${ }^{11}$ found that when confronting "self-determined" to "doctor-trusting" patients, it was not easy for doctors to anticipate the desired level of patient involvement in their healthcare shared decision-making.

A longitudinal study of student experiences in clinical learning conducted by Sointu ${ }^{12}$ concluded that 'bad' patients were considered mainly to have wrong priorities, little knowledge, and were difficult to deal with, while 'good' patients were active, compliant and knowledgeable. Labeling patients as 'good' or 'bad' has been also recognized to affect their abilities to make appropriate decisions. ${ }^{13}$

Free-form text analysis can be performed by almost instant automated information extraction using text-mining methods. However, because of the severe implications that errors may have in 
healthcare, potential benefits of human/natural language technologies must be carefully evaluated ${ }^{14}$. In the current study we explored a simple algorithm to automatically categorize patients' and physicians' responses by searching selected keywords throughout the free-form texts. Later, algorithm outcomes were compared with the classifications done by the psychologist/physician researcher. Globally, categorization of patients' opinions done by the algorithm was accurate for most groups.

This study has some limitations. First, although we did not try to make a difference between a 'poor' and a 'bad' doctor, surveyed patients included these categories together. For instance, a 'poor' doctor is generally credited with good intentions but inadequate knowledge or skills required for the job, while a 'bad' doctor, however skilled, is one with bad intentions, undesirable values, or serious defects of moral agency ${ }^{2}$. Second, since all the respondents were not critically-ill patients, most of them reported a good or very good self-rated health status; hence, this situation should be considered to interpret the current findings. Third, these findings are difficult to generalize since the patients' and doctors' responses are heavily influenced by our social and cultural context. Finally, until further investigation, the free-form text-mining analysis should be considered an exploratory approach.

In conclusion, this survey-based qualitative study gathered local information on patients' and physicians' opinions about what they considered is a good/bad doctor or patient, respectively. Although it was initially hypothesized that patients and doctors would have different views or priorities to characterize desirable individual's features, personality characteristics were in the foreground in both patients and physicians' selections. In addition to the human-based analysis, a text-mining algorithm was accurate to classify individuals' opinions into the different preset categories. Ideally, fusing the skills of the applied scientist to the reflective capabilities of the medical humanist will fulfill the archetype of what patients consider to be a 'good' doctor. Furthermore, doctors would be satisfied if patients manifested positive personality characteristics, were prone to avoid decisional and personal conflicts, had a high adherence to treatment, and trusted the doctor. These preferences reveal a "paternalistic" physician style, and his/her opinions should be managed carefully to avoid stigmatizing certain patients' behaviors.

\section{References}

1. Coulter A. Patients' views of the good doctor. BMJ 2002; 325: 668-9.

2. Hurwitz B, Vass A. What's a good doctor, and how can you make one? BMJ 2002; 325: 667-8.

3. Judge K, Salomon M. Public opinion and the National Health Service; patients and perspectives in consumer satisfaction. J Soc Policy 1993; 22: 299-327.

4. Jung HP, Baerveldt C, Olesen F, Grol R, Wensing M. Patient characteristics as predictors of primary health care preferences: a systematic literature analysis. Health Expect 2003; 6: 160-81.

5. Wensing M, Jung HP, Mainz, Olesen F, Grol R. A systematic review of the literature on patient priorities for general practice care. Part I: Description of the research domain. Soc Sci Med 1998; 47: 1573-88.

6. Grol R, Wensing M, Mainz J, Ferreira P, Hearnshaw $\mathrm{H}$, Hjortdahl $\mathrm{P}$, et al. Patients' priorities with respect to general practice care: an international comparison. European Task Force on Patient Evaluations of General Practice (EUROPEP). Fam Pract 1999; 16: 4-11.

7. Luthy C, Cedraschi C, Perrin E, Allaz AF. How do patients define 'good' and 'bad' doctors? Qualitative approach to the representations of hospital patients. Swiss Med Wkly 2005; 135: 82-6.

8. Jung HP, Wensing M, Grol R. What makes a good general practitioner: do patients and doctors have different views? Br J Gen Pract 1998; 47: 8059.

9. Deledda G, Moretti F, Rimondini M, Zimmermann C. How patients want their doctor to communicate. A literature review on primary care patients' perspective. Patient Educ Couns 2013; 90: 297-306.

10. Singletary B, Patel N, Heslin M. Patient Perceptions About Their Physician in 2 Words: The Good, the Bad, and the Ugly. JAMA Surg 2017; 152: 14169-70.

11. Wrede-Sach J, Voigt I, Diederichs-Egidi H, Hummers-Pradier E, Dierks ML, Junius-Walker U. Decision-making of older patients in context of the doctor-patient relationship: a typology ranging from "self-determined" to "doctor-trusting" patients. Int J Family Med 2013; 2013: 478498.

12. Sointu E. 'Good' patient/'bad' patient: clinical learning and the entrenching of inequality. Sociol Health Illn 2017: 39: 63-77.

13. Molina-Mula J. Good or bad patient: Labels that affect the patient's ability to make decisions. Enferm Clin 2017; 27: 203-5.

14. Suominen H. Text mining and information analysis of health documents. Artif Intell Med 2014; 61: 127 30. 